\title{
Simian Immunodeficiency Virus Infection of $\mathrm{CD} 8^{+}$ Lymphocytes In Vivo
}

\author{
GREGG A. DEAN,* GEHARD H. REUBEL, $\dagger$ AND NIELS C. PEDERSEN \\ Department of Medicine and Epidemiology, School of Veterinary Medicine, \\ University of California, Davis, California 95616
}

Received 1 May 1996/Accepted 3 May 1996

\begin{abstract}
To determine the lymphoid target cells of simian immunodeficiency virus (SIV) in vivo, peripheral blood lymphocytes (PBL) and lymph node lymphocytes (LNL) were positively selected (>97\% purity) for surface expression of CD4, CD8, or CD20 and then analyzed for SIV provirus using semiquantitative DNA amplification. We found provirus in $\mathrm{CD4}^{+}$and $\mathrm{CD8}^{+}$lymphocytes but none in $\mathrm{CD20}^{+}$lymphocytes. During acute SIV infection ( $\leq 214$ days postinoculation), the percentage of $\mathrm{PBL}$ and $\mathrm{LNL} \mathrm{CD4}{ }^{+}$cells containing proviral DNA ranged from 0.2 to $20 \%$ and from 0.2 to $2 \%$, respectively. Proviral burden in the $\mathrm{CD8}^{+}$population of either PBL or LNL ranged from 0.01 to $0.2 \%$. Virus isolation by cocultivation was positive for both $\mathrm{CD4}^{+}$and $\mathrm{CD8}^{+}$purified populations. No difference in proviral burden was observed between PBL and LNL subsets during acute SIV infection. Up to $19.4 \%$ of positively selected $\mathrm{CD8}^{+}$cells also expressed CD4, and thus the provirus may reside within a dual-positive population. This dual-positive population may represent activated lymphocytes that are particularly susceptible to infection and may provide an opportunity for virus entry into the $\mathrm{CDB}^{+}$ CD4 $^{-}$lymphocytes in vivo.
\end{abstract}

It has been clearly demonstrated that the CD4 molecule is the major receptor used by simian immunodeficiency viruses (SIV) for binding and entry into susceptible cells $(8,10,20)$. Similar to human immunodeficiency virus (HIV), SIV predominantly infects $\mathrm{CD}^{+}{ }^{+}$lymphocytes and macrophages. In addition, SIV has been reported to preferentially infect subsets of the $\mathrm{CD}^{+}{ }^{+}$lymphocyte population $(6,24)$. Studies of HIV have rigorously demonstrated that the virus rarely, if ever, infects $\mathrm{CD}^{+}$lymphocytes or B cells in vivo $(9,16,19)$. Similar studies regarding the in vivo lymphocyte target population of SIV have not been conducted, although there is evidence that SIV may productively infect $\mathrm{CD}^{+}$cells in vitro $(4,13,22)$.

To investigate the lymphocyte tropism of SIV in vivo, peripheral blood lymphocytes (PBL) from chronically $\mathrm{SIV}_{\mathrm{mac}^{-}}$ infected macaques and PBL and lymph node lymphocytes (LNL) from acutely SIV $_{\text {mac251-infected macaques were sorted }}$ by phenotype to high purity and semiquantitatively assayed for proviral DNA by PCR. Two groups of rhesus macaques were evaluated, and details of virus inoculum, route of inoculation, and time postinoculation at sampling are shown in Table 1. Additional details concerning virus inoculum, animal inoculation, and animals have previously been reported for group I (21) and group II animals (12).

Initially we sought to determine the lymphoid targets of SIV infection. Heparinized blood was drawn by venipuncture from five asymptomatic macaques that had been infected for approximately 11 months and from two sham-inoculated controls. Viable mononuclear cells were harvested from peripheral blood by density gradient centrifugation with Histopaque (1.077 $\rho$; Sigma, Saint Louis, Mo.). Mononuclear cells were incubated with fluorescein isothiocyanate- or phycoerythrin-

\footnotetext{
* Corresponding author. Mailing address: Department of Medicine, School of Veterinary Medicine, University of California, Davis, CA 95616. Phone: (916) 752-0748. Fax: (916) 752-0414. Electronic mail address: gadean@ucdavis.edu.

$\dagger$ Present address: School of Veterinary Science, University of Melbourne, Parkville, Victoria 3062, Australia.
}

conjugated monoclonal antibodies (MAbs) specific for CD4, CD8, or CD20 (Leu3a, Leu2a, and Leu16, respectively; Becton Dickinson, San Jose, Calif.) for $15 \mathrm{~min}$ at $4^{\circ} \mathrm{C}$. Cells were washed and then incubated with rat anti-mouse immunoglobulin G1 microbeads (Miltenyi Biotec, Auburn, Calif.) for 15 min at $4^{\circ} \mathrm{C}$. Cells were washed, and labeled cells were positively selected by magnetic cell sorting with a Mini-MACS (Miltenyi Biotec) as instructed by the manufacturer. The purity of cells was confirmed by flow cytometry with a FACScan (Becton Dickinson) and was $>97 \%$ for all samples tested (Fig. 1). Semiquantitative PCR was then performed on unfractionated and purified populations of lymphocytes by using a previously described method with minor modifications (23). From a tube containing $1.1 \times 10^{6}$ mononuclear cells in $110 \mu$ l of phosphatebuffered saline (PBS), 10-fold serial dilutions (10 $\mu \mathrm{l}$ transferred) were made into tubes containing $10^{6}$ peripheral blood

TABLE 1. Treatment groups and sampling

\begin{tabular}{cclll}
\hline Group & Animal & \multicolumn{1}{c}{ DPI } & SIV strain & \multicolumn{1}{c}{ Tissue $^{a}$} \\
\hline I & 24956 & & Control & Blood \\
I & 25580 & & Control & Blood \\
I & 24725 & 311 & SIV $_{\text {macbio }}$ & Blood \\
I & 25007 & 311 & SIV $_{\text {mac bio }}$ & Blood \\
I & 24951 & 322 & SIV $_{\text {mac }}$ bio & Blood \\
I & 19242 & 330 & SIV $_{\text {mac251 }}$ & Blood \\
I & 20624 & 330 & SIV $_{\text {mac251 }}$ & Blood \\
& & & & \\
II & 16954 & $14,55,214$ & SIV $_{\text {mac251 }}$ & Blood, lymph node \\
II & 17970 & 14,55 & SIV $_{\text {mac251 }}$ & Blood, lymph node \\
II & 21982 & 14,55 & SIV $_{\text {mac251 }}$ & Blood, lymph node \\
II & 19103 & 14,55 & SIV $_{\text {mac251 }}$ & Blood, lymph node \\
II & 23008 & 14,55 & SIV $_{\text {mac251 }}$ & Blood, lymph node \\
II & 18540 & 14,55 & SIV $_{\text {mac251 }}$ & Blood, lymph node \\
II & 18997 & $14,55,214$ & SIV $_{\text {mac251 }}$ & Blood, lymph node \\
II & 19825 & 14,55 & SIV $_{\text {mac251 }}$ & Blood, lymph node \\
II & 23363 & 14,55 & SIV $_{\text {mac251 }}$ & Blood, lymph node \\
\hline
\end{tabular}

${ }^{a}$ Tissue collected for analysis. 

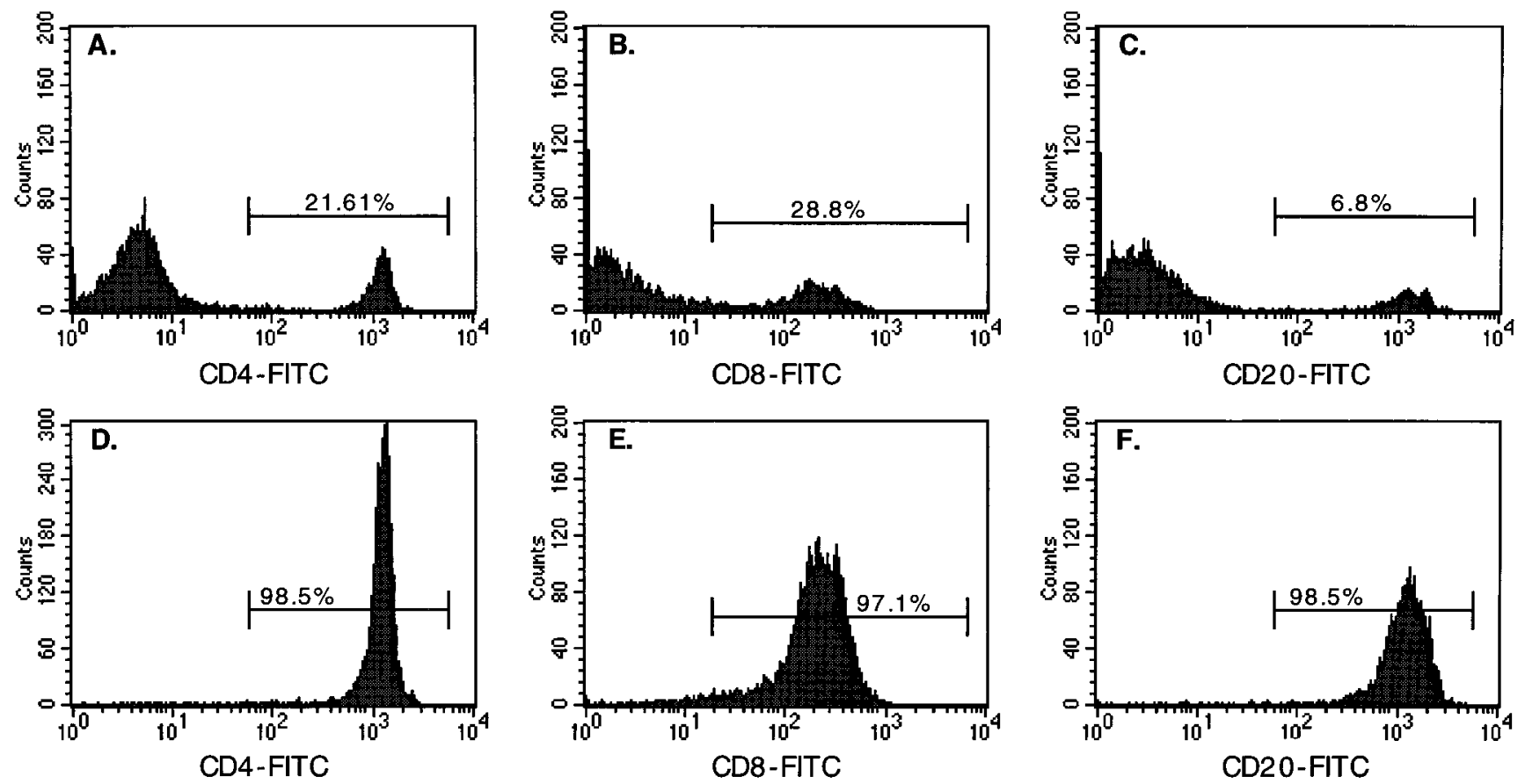

FIG. 1. Single-parameter flow cytometric analysis of lymphocytes before (A to C) and after (D to F) immunomagnetic purification. FITC, fluorescein isothiocyanate.

mononuclear cells in $100 \mu \mathrm{l}$ of PBS from an uninfected macaque. Thus, each dilution contained $10^{6}$ total cells, equalizing the concentration of DNA added to each PCR. Each dilution of cells was pelleted and lysed in $100 \mu \mathrm{l}$ of lysing buffer $(10 \mathrm{mM}$ TRIS-Cl [pH 8.3], 0.45\% Nonidet P-40, 0.45\% Tween 20, 50$\mu \mathrm{g} / \mathrm{ml}$ proteinase $\mathrm{K}$ ) and then incubated for $3 \mathrm{~h}$ at $56^{\circ} \mathrm{C}$ and for $10 \mathrm{~min}$ at $100^{\circ} \mathrm{C}$. Nested PCR was performed (on $10 \mu \mathrm{l}$ of cell lysate from each dilution) with primers specific for the SIV gag gene sequence (23). After two PCR rounds, each consisting of 35 cycles $\left(1 \mathrm{~min}\right.$ of template denaturation at $94^{\circ} \mathrm{C}, 1 \mathrm{~min}$ of primer annealing at $55^{\circ} \mathrm{C}$, and $1.5 \mathrm{~min}$ of primer extension at $72^{\circ} \mathrm{C}$ ), PCR products were analyzed by electrophoresis through a $2 \%$ agarose- $0.5 \times$ Tris-borate-EDTA electrophoresis buffer; this was followed by ethidium bromide staining. The end point was the last dilution of cells resulting in a positive PCR signal. From this, the minimum number of cells containing proviral SIV DNA could be determined. SIV-specific PCR products of $613 \mathrm{bp}$ (round 1) and $405 \mathrm{bp}$ (round 2) have been confirmed by Southern blotting. We have determined the sensitivity of this nested PCR to be between 1 and 10 SIV-infected cells or 1 to 10 SIV-containing plasmid copies per reaction.

In chronically infected animals, between 0.1 and $1.0 \%$ (average, $0.63 \%$ ) of $\mathrm{CD}^{+}$PBL contained proviral DNA (Fig. 2). This prevalence of provirus is similar to that previously reported for HIV and SIV (3, 16, 18-20). For each animal tested, a mean of $0.001 \%$ of the purified B-cell population contained proviral DNA. This is the expected value considering $1 \%$ contamination of $\mathrm{B}$ cells by $\mathrm{CD} 4^{+}$cells with an infectivity rate of $1 \%$ or less. Surprisingly, $\mathrm{CD}^{+}$cells contained a mean of $0.046 \%$ infected cells, which is more than a log greater than would be anticipated from $\mathrm{CD} 4{ }^{+}$cell contamination as observed in the purified B-cell population. Thus, it was apparent that $\mathrm{CD} 8^{+}$ lymphocytes were infected by SIV $_{\text {mac }}$ in vivo.

A relatively large population of $\mathrm{CD}^{+} \mathrm{CD} 8^{+}$has been described for macaques, and we have observed this population frequently in our routine analysis of the macaque PBL pheno- type (Fig. 3) (17). Although we knew $\mathrm{CD} 4^{+} \mathrm{CD}^{+}$cells were present in the unfractionated PBL population from each of the chronically infected animals, we could not assay the purified $\mathrm{CD}^{+}$population for $\mathrm{CD} 4$ expression because of reagent cross-reactivity (anti-mouse immunoglobulin $\mathrm{G}$ microbeads were used in the purification scheme).

To further investigate the presence of proviral DNA in $\mathrm{CD}^{+}$cells and to evaluate the proviral burden in PBL and LNL of acutely infected macaques, sequential samples from nine SIV-inoculated animals were evaluated. The nine female rhesus macaques were inoculated with a $10^{3}$ to $10^{4}$ tissue culture infective dose intravaginally. PBL and LNL were collected at 14 and 55 days from all nine animals and at 214 days from two animals (Table 1). Lymphocytes were fractionated as described above except $\mathrm{CD}^{+}$cells were positively selected with

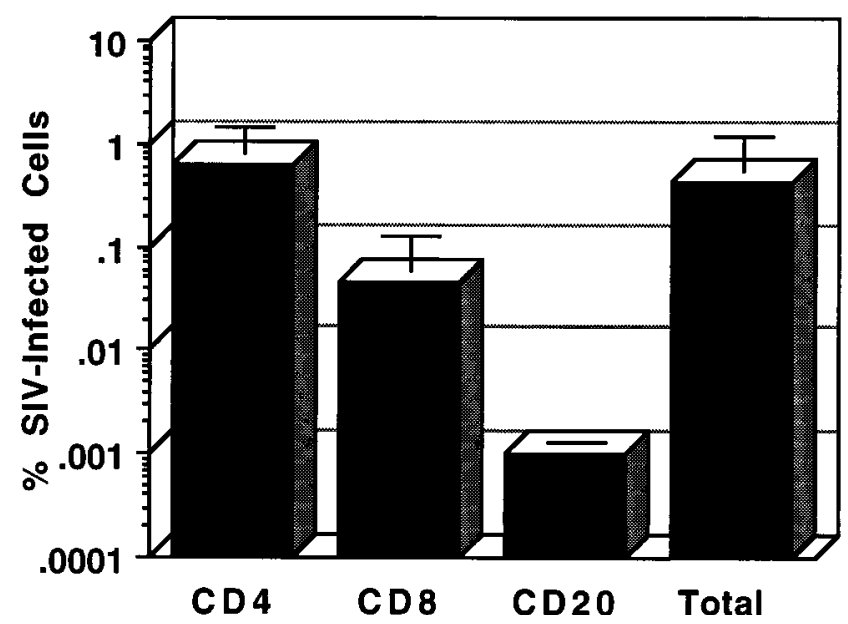

FIG. 2. Frequency of SIV provirus-containing cells within PBL subsets in rhesus macaques infected with SIV $_{\text {mac }}$ for $\geq 311$ days. 


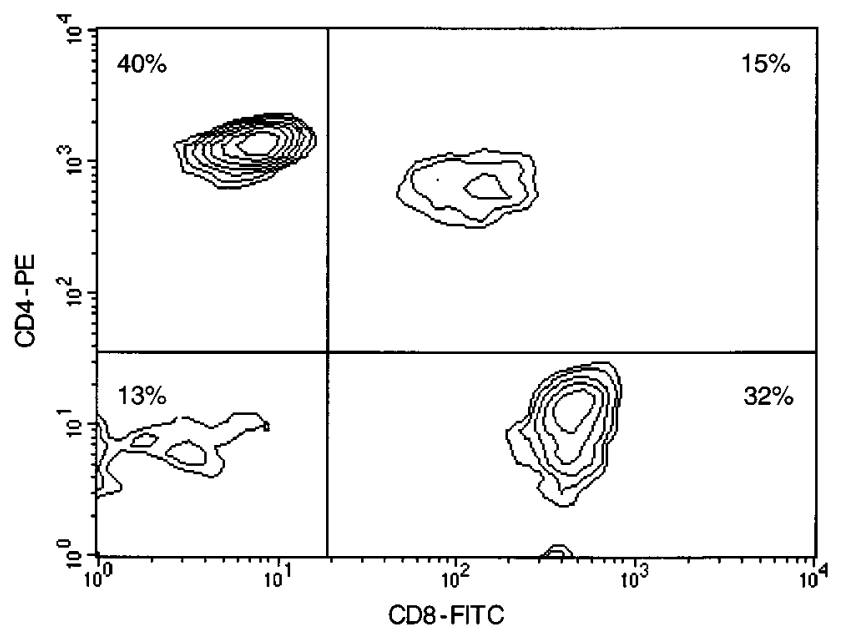

FIG. 3. Dual-parameter histogram showing staining of CD4 and CD8 on rhesus macaque lymphocytes. The upper right quadrant contains a dual-positive, CD4hi CD8dim population. PE, phycoerythrin; FITC, fluorescein isothiocyanate.

microbeads coated with the anti-CD8 mouse MAb, Leu2a (Miltenyi Biotec). Purified CD8-bearing cells were then labeled with Leu3a-phycoerythrin (anti-CD4 MAb) to determine the percentage of $\mathrm{CD} 4^{+} \mathrm{CD} 8^{+}$cells in the purified fraction. $\mathrm{B}$ cells were not evaluated since it was clear from the previous experiment that no proviral DNA was harbored in this population. Of nine inoculated animals, three became persistently viremic, four were transiently viremic, and two were consistently virus isolation negative (12). Only the three persistently viremic animals were PCR positive at any time, in fractionated and unfractionated lymph node or peripheral blood. PCR status was confirmed independently by two laboratories (12).

At 14 days postinoculation (DPI), the percentage of PBL $\mathrm{CD}^{+}{ }^{+}$cells containing proviral DNA ranged from 0.2 to $20 \%$ and from 0.2 to $2 \%$ in lymph node. The range and mean did not change significantly for PBL and $\mathrm{LNL} \mathrm{CD}^{+}$cells at 54 and 214 DPI (Fig. 4 and 5). A comparison of viral burden in
TABLE 2. Presence of SIV infection in positively selected $\mathrm{CD}^{+}$population

\begin{tabular}{lclcrc}
\hline Animal & DPI & \multicolumn{1}{c}{ Tissue } & $\begin{array}{c}\text { \% CD8 } \\
\text { Purity }\end{array}$ & $\begin{array}{r}\text { \% CD4 }{ }^{+} \\
\text {CD8 }{ }^{+}\end{array}$ & $\begin{array}{c}\text { \% SIV } \\
\text { infection }\end{array}$ \\
\hline 16954 & 14 & Blood & 99.39 & 3.15 & 0.02 \\
16954 & 55 & Blood & 99.14 & 4.42 & 0.2 \\
23008 & 55 & Blood & 98.22 & 2.82 & 0.2 \\
18997 & 55 & Blood & 98.83 & 12.80 & 0.01 \\
16954 & 55 & Lymph node & 98.92 & 1.88 & 0.1 \\
23008 & 55 & Lymph node & 98.92 & 3.70 & 0.1 \\
18997 & 55 & Lymph node & 98.76 & 19.40 & 0.01 \\
\hline
\end{tabular}

fractionated and unfractionated PBL and LNL revealed no significant difference between the two lymphoid compartments (Fig. 6). Virus isolation by cocultivation of purified subsets with CEMx174 cells demonstrated that both $\mathrm{CD}^{+}$and $\mathrm{CD} 8^{+}$ cells were productively infected (data not shown). In this prospective experiment, there were three instances when the number of infected cells was equal in the $\mathrm{CD}^{+}$population and the $\mathrm{CD} 4^{+}$population. This further supports our conclusion that $\mathrm{CD}^{+}$cells are infected by SIV.

The proviral burden associated with acute and chronic $\mathrm{SIV}_{\text {mac }}$ infection was similar to that reported for HIV and other SIV isolates. However, in contrast to studies of HIV-1infected humans, no significant difference in viral burden was observed between the circulating and lymph node compartments $(7,15)$. Perhaps a difference between compartments would have been apparent during the clinically asymptomatic phase when a dramatic 10-fold decline in proviral load in peripheral lymphocytes was observed. Unfortunately, no lymph node sample was available for comparison at the 214 DPI time point.

The mean $\mathrm{CD}^{+} \mathrm{CD}^{+}$percentage of all animals (nine animals evaluated at 14 and 54 DPI) was 5.8 and $2.2 \%$ in PBL and LNL, respectively. After sorting, the mean $\mathrm{CD} 4^{+} \mathrm{CD}^{+}$percentage in the positively selected $\mathrm{CD}^{+}$population was 10.2 and $13.8 \%$ for PBL and LNL, respectively. Proviral burden in the $\mathrm{CD}{ }^{+}$population of either PBL or LNL at 14 and 54 DPI ranged from 0.01 to $0.2 \%$ (Table 2 ). Thus, the proviral burden

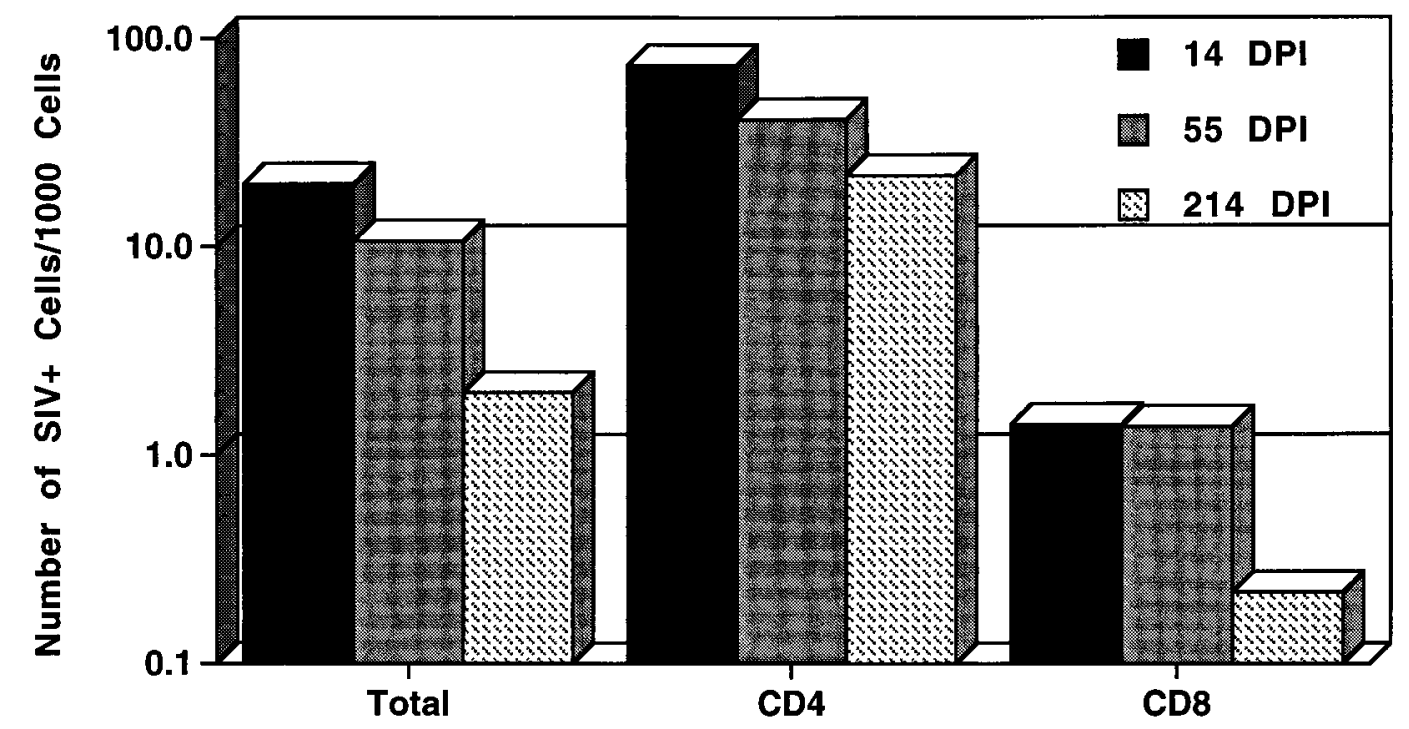

FIG. 4. Frequency of SIV provirus-containing cells within PBL subsets in rhesus macaques acutely infected with $\mathrm{SIV}$ mac251. $N=3$ at 14 and $55 \mathrm{DPI} ; N=2$ at $214 \mathrm{DPI}$. 


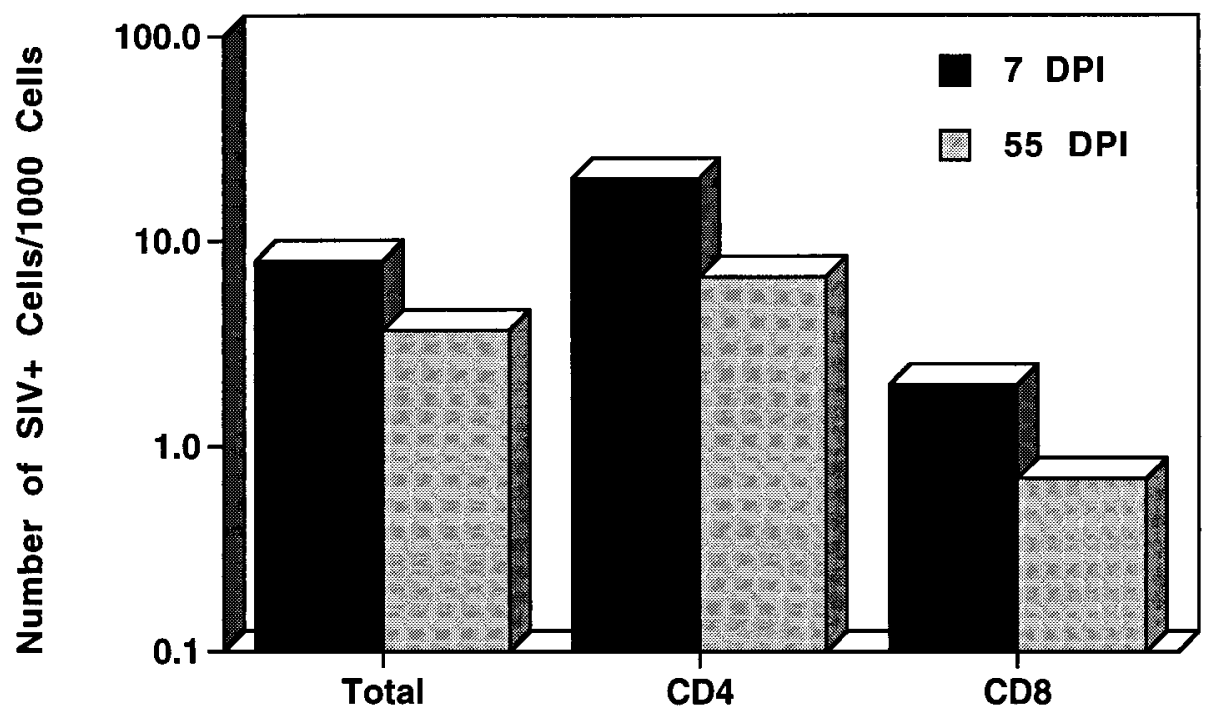

FIG. 5. Frequency of SIV provirus-containing cells within LNL subsets in rhesus macaques acutely infected with $\operatorname{SIV}_{\text {mac251. }} . N=3$.

within the $\mathrm{CD}^{+}$population could mathematically reside entirely within the dual-positive subpopulation.

Cells expressing both CD4 and CD8 are observed in approximately $3 \%$ of human peripheral lymphocytes. $\mathrm{CD}^{+} \mathrm{CD}^{+}$ cells in peripheral circulation are characterized as larger, blastlike cells expressing interleukin-2 receptor, thus indicating these cells are activated (1). In vitro, both $\mathrm{CD}^{+} \mathrm{CD}^{-}$and $\mathrm{CD}^{+} \mathrm{CD}^{-}$cells have been shown to coexpress CD4 and CD8 antigens after lectin mitogen stimulation (2). Moreover, mitogen-stimulated $\mathrm{CD}^{+}{ }^{+} \mathrm{CD}^{-}$cells that subsequently express both antigens can go on to become either $\mathrm{CD} 4^{+} \mathrm{CD} 8^{-}$ or $\mathrm{CD}^{+} \mathrm{CD}^{-}$cells (5). Coexpression of CD4 and CD8 is reported to occur on 0 to $10 \%$ of PBL in rhesus macaques. In these studies, we report coexpression in up to $15 \%$ of circulating lymphocytes, but coexpression in up to $34.8 \%$ of such cells has been observed (C. Chang-Mayer, personal communication). An emergence of $\mathrm{CD}^{+}{ }^{+} \mathrm{CD} 8^{+}$cells has been associ- ated with human T-cell leukemia virus type 1, Epstein-Barr virus, autoimmune disorders, and neoplastic conditions (11, 14). The intensity of CD4 and CD8 expression on dual-positive cells has been associated with various disease etiologies (11, 14). In healthy humans, CD4hi CD8dim cells predominate and this is the phenotype we observed in rhesus macaques $(11,14)$. In addition, we observed no changes in percentage or expression intensity of the $\mathrm{CD} 4^{+} \mathrm{CD} 8^{+}$population associated with SIV infection.

SIV-infected $\mathrm{CD}^{+}$cells have previously been described from in vitro studies. In one report, long-term cultures from SIV-infected macaques, consisting predominantly of $\mathrm{CD}^{+}$ $\mathrm{CD}^{-}$T cells, were proven to be productively SIV infected by reverse transcriptase activity in culture supernatants, radioimmunoprecipitation of SIV proteins, immunoelectron microscopy demonstrating viral particles and cell phenotype, and immunohistochemistry demonstrating viral core antigen and

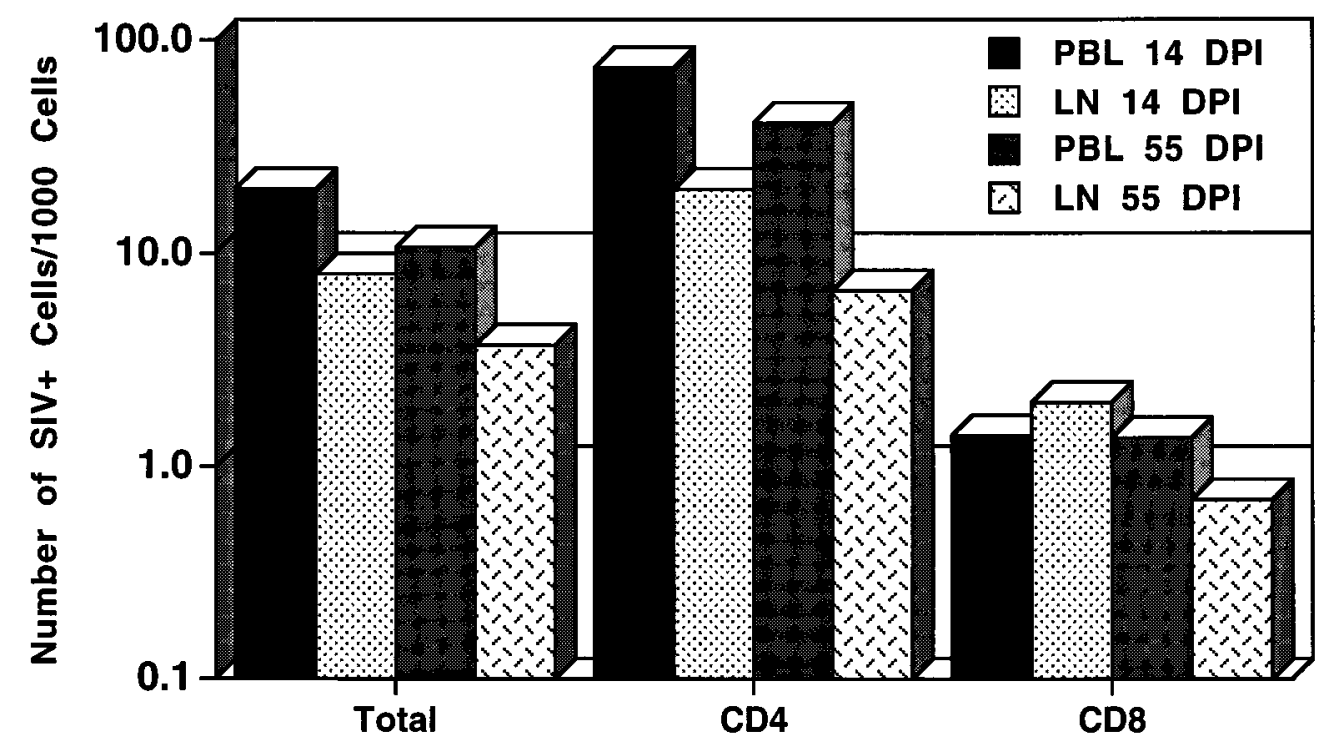

FIG. 6. Comparison of frequency of SIV provirus-containing cells within PBL and LNL subsets in rhesus macaques acutely infected with $\mathrm{SIV}_{\text {mac251. }} N=3$. 
cell phenotype (22). In the same study, $\mathrm{CD} 4^{-} \mathrm{CD}^{+}$cells expressing core antigen were identified in cultures of HIVinfected humans. However, attempts to infect macaque CD4 ${ }^{-}$ $\mathrm{CD}^{+}$cells with SIV were unsuccessful. In a study of SIVkilling kinetics of PBL in vitro, $\mathrm{CD}^{+}$cells were shown to be not only infected but also killed during a burst of viral replication (13). Studies presented here demonstrate SIV infection of $\mathrm{CD}^{+}$cells in vivo. Taken together with previous in vitro data, it is likely these cells are infected when CD4 and CD8 are coexpressed, probably when activated. Further studies to answer the questions of whether SIV persists in $\mathrm{CD}^{+} \mathrm{CD}^{-}$ cells and whether the infection is cytopathic will require fluorescence-activated cell sorting, a resource that is not widely available for such biohazardous samples.

This study was supported by NIAID grants AI01262 and AI07398. We gratefully acknowledge Marta Marthas, Christopher Miller, Satya Dandekar, and Linda Antipa for providing the blood and lymph node samples and Carol Oxford and Harry Louie for expert technical assistance.

\section{REFERENCES}

1. Blue, M. L., J. F. Daley, H. Levine, K. A. Craig, and S. F. Schlossman. 1986. Biosynthesis and surface expression of $\mathrm{T} 8$ by peripheral blood $\mathrm{T} 4{ }^{+}$cells in vitro. J. Immunol. 137:1202-1207.

2. Blue, M. L., J. F. Daley, H. Levine, and S. F. Schlossman. 1985. Coexpression of T4 and T8 on peripheral blood T cells demonstrated by two-color fluorescence flow cytometry. J. Immunol. 134:2281-2286.

3. Brinchmann, J. E., J. Albert, and F. Vartdal. 1991. Few infected CD4 ${ }^{+} \mathrm{T}$ cells but a high proportion of replication-competent provirus copies in asymptomatic human immunodeficiency virus type 1 infection. J. Virol. 65: 2019-2023.

4. Daniel, M. D., N. L. Letvin, N. W. King, M. Kannagi, P. K. Sehgal, R. D. Hunt, P. J. Kanki, M. Essex, and R. C. Desrosiers. 1989. Isolation of T-cell tropic HTLV-III-like retrovirus from macaques. J. Immunol. 143:1201-1204.

5. Farcet, J. P., M. F. Gourdin, C. Calvo, N. Oudrhiri, M. Divine, J. Bouguet, D. Fradelizzi, A. Senik, and F. Reyes. 1985. A subset of OKT4+ peripheral $\mathrm{T}$ cells can generate colonies containing mixed progeny with OKT4+ helper and OKT8+ suppressor cells. Eur. J. Immunol. 15:1067-1073.

6. Gallatin, W. M., M. J. Gale, P. A. Hoffman, D. M. Willerford, K. E. Draves, R. E. Benveniste, W. R. Morton, and E. A. Clark. 1989. Selective replication of simian immunodeficiency virus in a subset of CD4+ lymphocytes. Proc. Natl. Acad. Sci. USA 86:3301-3305.

7. Graziosi, C., G. Pantaleo, J. F. Demarest, O. J. Cohen, M. Vaccarezza, L. Butini, M. Montroni, and A. S. Fauci. 1993. HIV-1 infection in the lymphoid organs. AIDS 7(Suppl. 2):S53-S58.

8. Hoxie, J. A., B. S. Haggarty, S. E. Bonser, J. L. Rackowski, H. Shan, and P. J. Kanki. 1988. Biological characterization of a simian immunodeficiency viruslike retrovirus (HTLV-IV): evidence for CD4-associated molecules required for infection. J. Virol. 62:2557-2568.

9. Hufert, F. T., D. von Laer, C. Schramm, A. Tarnok, and H. Schmitz. 1989. Detection of HIV-1 DNA in different subsets of human peripheral blood mononuclear cells using the polymerase chain reaction. Rapid communication. Arch. Virol. 106:341-345.
10. Koenig, S., V. M. Hirsch, R. A. Olmsted, D. Powell, W. Maury, A. Rabson, A. S. Fauci, R. H. Purcell, and P. R. Johnson. 1989. Selective infection of human CD4+ cells by simian immunodeficiency virus: productive infection associated with envelope glycoprotein-induced fusion. Proc. Natl. Acad. Sci. USA 86:2443-2447.

11. Macchi, B., G. Graziani, J. Zhang, and A. Mastino. 1993. Emergence of double-positive $\mathrm{CD} 4 / \mathrm{CD} 8$ cells from adult peripheral blood mononuclear cells infected with human T cell leukemia virus type I (HTLV-I). Cell. Immunol. 149:376-389.

12. Miller, C. J., M. Marthas, J. Torten, N. J. Alexander, J. P. Moore, G. F. Doncel, and A. G. Hendrickx. 1994. Intravaginal inoculation of rhesus macaques with cell-free simian immunodeficiency virus results in persistent or transient viremia. J. Virol. 68:6391-6400.

13. Montaner, L. J., D. J. Ringler, M. S. Wyand, M. R. Mattmuller, J. J. MacKey, D. K. Schmidt, M. D. Daniel, and N. W. King. 1990. Study of long-term cultures of simian immunodeficiency virus (SIVmac 251)-infected peripheral blood lymphocytes. Lab. Invest. 63:242-247.

14. Ortolani, C., E. Forti, E. Radin, R. Cibin, and A. Cossarizza. 1993. Cytofluorimetric identification of two populations of double positive $(\mathrm{CD} 4+, \mathrm{CD} 8+)$ $\mathrm{T}$ lymphocytes in human peripheral blood. Biochem. Biophys. Res. Commun. 191:601-609.

15. Pantaleo, G., C. Graziosi, L. Butini, P. A. Pizzo, S. M. Schnittman, D. P. Kotler, and A. S. Fauci. 1991. Lymphoid organs function as major reservoirs for human immunodeficiency virus. Proc. Natl. Acad. Sci. USA 88:98389842.

16. Psallidopoulos, M. C., S. M. Schnittman, L. M. Thompson III, M. Baseler, A. S. Fauci, H. C. Lane, and N. P. Salzman. 1989. Integrated proviral human immunodeficiency virus type 1 is present in $\mathrm{CD}^{+}$peripheral blood lymphocytes in healthy seropositive individuals. J. Virol. 63:4626-4631.

17. Reimann, K. A., B. C. Waite, P. D. Lee, W. Lin, Z. B. Uchanska, M. J. O'Connell, and N. L. Letvin. 1994. Use of human leukocyte-specific monoclonal antibodies for clinically immunophenotyping lymphocytes of rhesus monkeys. Cytometry 17:102-108.

18. Schnittman, S. M., J. J. Greenhouse, M. C. Psallidopoulos, M. Baseler, N. P. Salzman, A. S. Fauci, and H. C. Lane. 1990. Increasing viral burden in CD4+ $\mathrm{T}$ cells from patients with human immunodeficiency virus (HIV) infection reflects rapidly progressive immunosuppression and clinical disease. Ann. Intern. Med. 113:438-443.

19. Schnittman, S. M., M. C. Psallidopoulos, H. C. Lane, L. Thompson, M Baseler, F. Massari, C. H. Fox, N. P. Salzman, and A. S. Fauci. 1989. The reservoir for HIV-1 in human peripheral blood is a $\mathrm{T}$ cell that maintains expression of CD4. Science 245:305-308.

20. Schwiebert, R., and P. N. Fultz. 1994. Immune activation and viral burden in acute disease induced by simian immunodeficiency virus SIVsmmPBj14: correlation between in vitro and in vivo events. J. Virol. 68:5538-5547.

21. Stone, J. D., C. C. Heise, C. J. Miller, C. H. Halsted, and S. Dandekar. 1994 Development of malabsorption and nutritional complications in simian immunodeficiency virus-infected rhesus macaques. AIDS 8:1245-1256.

22. Tsubota, H., D. J. Ringler, M. Kannagi, N. W. King, K. R. Solomon, J. J. MacKey, D. G. Walsh, and N. L. Letvin. 1989. CD8+CD4- lymphocyte lines can harbor the AIDS virus in vitro. J. Immunol. 143:858-863.

23. Unger, R. E., M. L. Marthas, A. A. Lackner, L. E. Pratt, B. L. Lohman, R. K. Van, and P. A. Luciw. 1992. Detection of simian immunodeficiency virus DNA in macrophages from infected rhesus macaques. J. Med. Primatol. 21: 74-81.

24. Willerford, D. M., M. J. Gale, R. E. Benveniste, E. A. Clark, and W. M Gallatin. 1990. Simian immunodeficiency virus is restricted to a subset of blood CD4+ lymphocytes that includes memory cells. J. Immunol. 144:37793783 . 